НІЧОГА В. О., доктор технічних наук, професор, ШКЛЯРСЬКИЙ В. І., доктор технічних наук, професор, СТОРОЖ В. Г., кандидат технічних наук, доцент, МАТІЄШИН Ю. М., кандидат технічних наук, асистент, ВАЩИШИН Л. В., молодший науковий співробітник (Національний університет «Львівська політехніка»)

\title{
Дослідження сучасних методів і засобів швидкісної діагностики дефектів залізничних рейок (огляд)
}

Завданням мобільної діагностики дефектів залізничних колій є виявлення $і$ розпізнавання небезпечних дефектів з метою попередження можливих аварій. Огляд методів контролю фізико-механічних характеристик металевих конструкцій інженерних об'єктів довготривалої експлуатаџіï, які використовуються при різних температурних режимах та умовах, здійснено в [1, 2]. Серед описаних неруйнівних методів за використовуваними фізичними полями виділяють: магнітні, акустичні, електромагнітні, теплові та електричні.

Ключові слова: інформаційно-діагностична система, дефектоскопія залізничних колій, компонентні давачі, неруйнівні магнітні методи, вейвлет-аналіз та нейронні мережі.

\begin{abstract}
Вступ
Сьогодні залізничні мережі по всьому світу стають все більш завантаженими високошвидкісними поїздами 3 великою кількістю пасажирів і важких товарних вагонів, які створюють більші навантаження на залізничні коліі, ніж раніше. Все це призводить до збільшення потреб в контролі та технічному обслуговуванні залізничних колій. Витрати на огляд та технічне обслуговування залізничних колій протягом останніх декількох років неухильно зростають, що супроводжується значним поліпшенням якісних показників в цій галузі:
\end{abstract}

а) підвищення безпеки залізничної системи;

б) розвиток нових залізничних мереж для задоволення постійно зростаючого попиту;

в) сприяння вищій стабільності залізничних мереж, як в екологічному, так і в фінансовому відношенні, шляхом забезпечення постійного підвищення ефективності і використання технологічних інновацій.

Таким чином, максимальна надійність залізничної мережі може бути досягнута тільки після достатньої і надійної перевірки та технічного обслуговування рейкової мережі. Рання дефектоскопія рейок виконує першочергову роль в процесі виявлення та розпізнавання небезпечних тріщин на рейках від прокатної контактної втоми (ПКВ) 3 метою попередження можливих аварій і тому має першорядне значення для безпечної та надійної експлуатації залізничних мереж по всьому світу.

Незважаючи на це, залізнична техніка неруйнівної мобільної діагностики дефектів довгий час не отримувала достатнього фінансування. Воно стало більш доступним тільки після ряду серйозних аварій (наприклад, у місті Хетфілд (графство Хартфордшир, Східна Англія, жовтень 2000 року)). Належне використання обмеженого фінансування у цьому випадку є дуже важливим.

\section{Аналіз останніх досліджень та публікацій}

Огляд методів контролю фізико-механічних характеристик металевих конструкцій інженерних об'єктів довготривалої експлуатації, які використовуються при різних температурних режимах та умовах, здійснено в $[1,2]$.

Серед магнітних неруйнівних методів контролю, які віддавна використовують у мобільній діагностиці дефектів залізничних колій, найбільш поширеними $є$ магнітодинамічний метод та метод вимірювання поля змінного струму [3]. Магнітні методи дефектоскопії добре діагностують верхню частину рейки, фактично головку рейки.

Вагоме місце в дефектоскопії залізничних рейок займають також ультразвукові методи [4-6]. Ультразвукові методи діагностики, незважаючи на труднощі забезпечення надійного акустичного контакту 3 поверхнею рейки, необхідність великої кількості контактної рідини та обмеження швидкості діагностики, можуть діагностувати шийку і підошву рейки. Перевагою ультразвукових методів $\epsilon$ також можливість оцінки розмірів і положення дефекту, що в кінцевому результаті забезпечило інтенсивний розвиток досліджень у цьому напрямку $[1,7]$.

() В. О. Нічога, В. І. Шклярський, В. Г. Сторож, Ю. М. Матієшин, Л. В. Ващишин, 2018 
На рис. 1 показаний принцип вимірювання поперечних, поздовжніх та кутових тріщин головки рейки за допомогою набору 3 трьох ультразвукових давачів, розміщених під різними кутами по відношенню до поверхні рейки. Також на цьому рисунку наведений поперечний переріз рейки разом 3 розташованим на ній набором давачів.
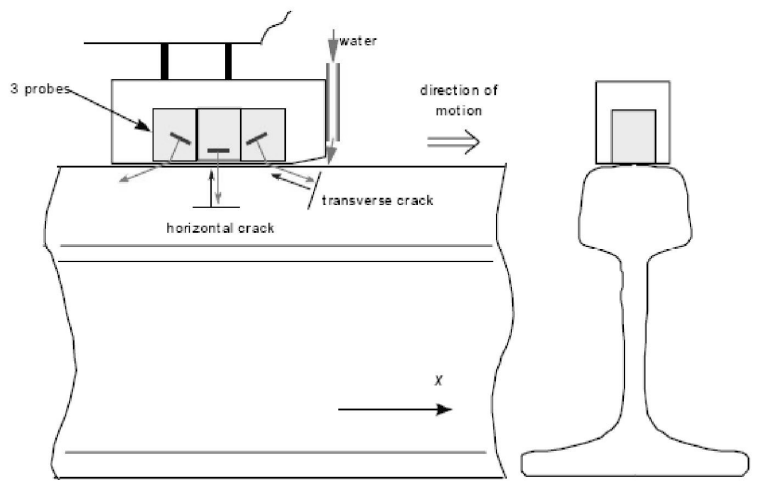

Рис. 1. Вимірювання дефектів в залізничній рейці ультразвуковим методом [1]

Електромагнітні методи успішно використовуються в різних галузях промисловості, таких як залізнична галузь, металопрокатна промисловість, буріння, зберігання ядерних відходів тощо [3]. Зокрема, у залізничній галузі за допомогою техніки вимірювання електромагнітного поля змінного струму здійснюється перевірка вагонів, колісних пар та колій.

Останнім часом активно застосовуються гібридні системи діагностики на базі вагонів-дефектоскопів при одночасному використанні для виявлення дефектів залізничних колій магнітних, ультразвукових, візуально-вимірювальних та оптичних методів неруйнівного контролю [1].

Висока ефективність нових методів для побудови ІДС мобільної магнітної дефектоскопії залізничних колій об'єктивно залежить від успішного вирішення певного протиріччя: це забезпечення високої роздільної здатності і чутливості ІДС для виявлення, розрізнення і класифікації сигналів дефектів - з одного боку, а з іншого боку - скорочення часу, відведеного на дефектоскопічне обстеження, та підвищення точності діагностики в умовах різноманітних завад та сигналів від шпальних підкладок і необхідності виявлення дефектів на ранніх стадіях їх розвитку. Вирішення цього протиріччя 3 використанням сучасних методів опрацювання нестаціонарних сигналів від дефектів залізничних колій шляхом застосування вейвлет-перетворень та нейронних мереж i побудови діагностичної системи на основі нових малогабаритних багатоканальних i компонентних сенсорів складає зміст важливої прикладної задачі.

\section{Основна частина}

Ультразвукові методи мобільної діагностики дефектів залізничних колій

Ультразвукове випробувальне обладнання широко використовується в залізничній галузі для перевірки наявності будь-яких внутрішніх дефектів та контролю рейок в режимі експлуатації.

У більшості випадків перевірка рейок проводиться за допомогою спеціальних ультразвукових давачів, встановлених на шасі випробувального поїзда. Для з'єднання п'єзоелектричних перетворювачів та рейок використовуються ковзні сани-пластини або заповнені рідиною ультразвукові колісні давачі. Стандартні ультразвукові давачі мають погану здатність виявлення, коли дефекти $\epsilon$ поверхневі або приповерхневі. 3 цієї причини використовують набір давачів, які розміщені під різними кутами для того, щоб забезпечити виявлення поверхневих i приповерхневих дефектів (рис. 2).
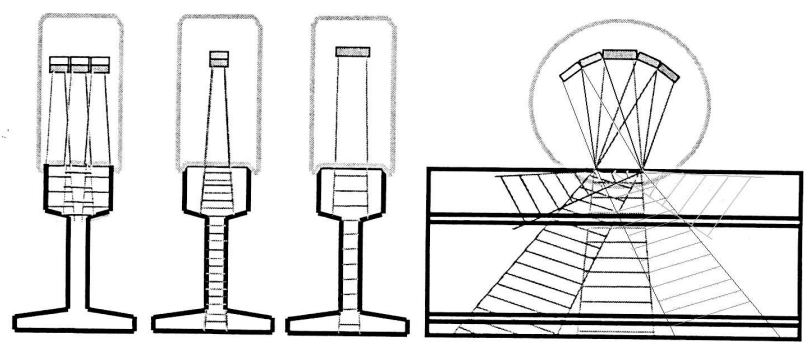

Рис. 2. Збільшення можливості виявлення дефектів за рахунок використання набору давачів [1]

Під час діагностики рейок 3 використанням звичайних ультразвукових давачів промінь ультразвукової енергії у вигляді коливання передається тілу рейки. Відбита енергія ультразвукового коливання детектується за допомогою набору перетворювачів. Амплітуда будь-яких відбитих імпульсів під час діагностики містить цінну інформацію про цілісність рейки та їі дефекти. Оскільки положення дефектів $\epsilon$ непередбачуваним, поширення ультразвукового коливання в рейці відбувається під різними кутами падіння, з тим, щоб максимізувати ймовірність виявлення будь-яких небезпечних дефектів, наявних в рейці. Зазвичай використовують кути падіння 0, 37 або 45 і $70^{\circ}$.

У багатьох країнах цей метод зазвичай використовується на діагностичних поїздах Sperry (моделі «UTU1», «UTU2» та «UTU5» - англ. Ultrasonic rail Testing Unit (UTU)). Наявність дефектів, виявлених за допомогою поїздів типу UTU, підтверджується за допомогою розгортання портативних ультразвукових інспекційних блоків, відомих як Sperry Stick. На рисунку 3, а показаний такий типовий портативний 
ультразвуковий пристрій для контролю залізничної колії, що керується оператором [1].

Діагностичні поїзди Eurailscout (Нідерланди, Німеччина та ін.) та Scanmaster (Ізраїль) використовують ковзні сани-пластини для розміщення системи ультразвукових зондів, як показано на рисунку 3, б. Ці поїзди працюють зі швидкістю 72 км/год, але потенційно можлива швидкість інспекції сягає до 100 км/год [1].
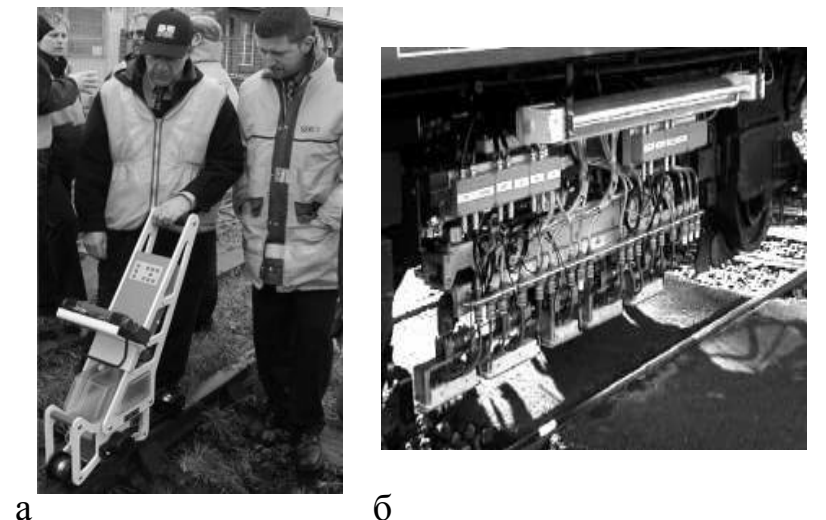

Рис. 3. Техніка ультразвукової дефектоскопії [1]

Одна $з$ проблем, 3 якою стикаються поїзди типу UTU1 - велика кількість “хибних" спрацювань, що збільшує затрати часу у персоналу, оскільки кожне таке спрацювання повинно бути детально досліджено. Частково ця проблема вирішується шляхом збільшення порогу спрацювання i порівняння результатів діагностичного поїзда із результатами портативних систем для уточнення критеріїв виявлення.

Зонд UTU2 містить великий масив давачів, що забезпечує краще та більш повне опромінювання рейки ультразвуком. Масив давачів, який складається 3 дев'яти окремих сенсорів, міститься всередині заповненої рідиною шини, відомої як роликовий блок пошуку (РБП). UTU2 має два таких блоки, щоб забезпечити тестування, якщо один РБП не зможе правильно функціонувати чи відмовить.

Портативний ультразвуковий інспекційний пристрій Sperry Stick $€$ ручною версією РБП i використовується як засіб для перевірки даних обох типів ультразвукових поїздів. Порівняння результатів 3 блоків UTU2 та Sperry Stick показує збіг результатів ідентифікації дефектів на 90-95\%.

Розвитком та вдосконаленням цих систем, з метою скорочення часу, відведеного на дефектоскопічне обстеження шляхом підвищення швидкості сканування, займаються США та Великобританія (компанія Network Rail). UTU2 може працювати на швидкості до 65 км/год, однак, для забезпечення високої точності давачі повинні опромінити дефект ультразвуком чотири рази і тому на практиці вони працюють при швидкості 45 км/год. Використання діагностичних поїздів UTU5 дозволяє на $40 \%$ швидше, ефективніше та надійніше виявляти дефекти рейок та їх болтових з'єднань (в тому числі і їх розтріскування). Це забезпечується високою відповідністю форми шини РБП до форми поверхні рейки, навіть при великому зношенні та деформації останньої.

Устаткування на поїздах типу UTU не визначає розміри всіх наявних дефектів та їх точне розташування. За допомогою цього обладнання можна надійно виявляти тільки дефекти у вигляді глибоких тріщин в діапазоні кутів $15-25^{\circ}$ від вертикалі у будьякому напрямку. Тріщини розміром менше 5 мм в глибину та тріщини, розташовані під іншими кутами, виявити складно. Це складає основні проблеми та обмеження, з якими стикаються поїзди типу UTU:

- дуже холодна погода, утворення проміжного шару внаслідок обледеніння колії;

- розлите мастило, яке також приводить до виникнення проміжного шару, що може вплинути на результати обстеження навіть до 100 м від РБП;

- руйнування шини РБП пошкодженою рейкою, що відбувається в середньому один раз на тиждень;

- складність визначення вертикальних/поперечних дефектів;

- низька швидкість процедури діагностики дефектів за допомогою портативного дефектоскопа РБП (2-3 км/год).

\section{Магнітні методи мобільної діагностики дефектів залізничних колій \\ Магнітні методи у дефектоскопії рейок мають} давню історію. Зародженням магнітного методу контролю рейок можна вважати кінець 20-х - початок 30-х років минулого сторіччя. Саме в цей час (в 1928 році), в Японії, М. Сузукі запропонував перший магнітний дефектоскоп, який являв собою самохідну дрезину, обладнану системою намагнічування у вигляді П-подібного електромагніту постійного струму (на кожній нитці колії) i індукційними давачами, розміщеними між полюсами електромагніту та пристроєм для реєстрації результатів контролю на паперову стрічку. Цей дефектоскоп дозволяв виявляти внутрішні дефекти головки рейки, а також тріщини 3 виходом на поверхню рейки при швидкості руху дефектоскопа до 4 км/год.

Також в 1928 році, на замовлення фірми “ARA" (American Railway Association), Елмер Сперрі розробив дефектоскоп для виявлення поперечних тріщин в головці рейки (рис. 4). 


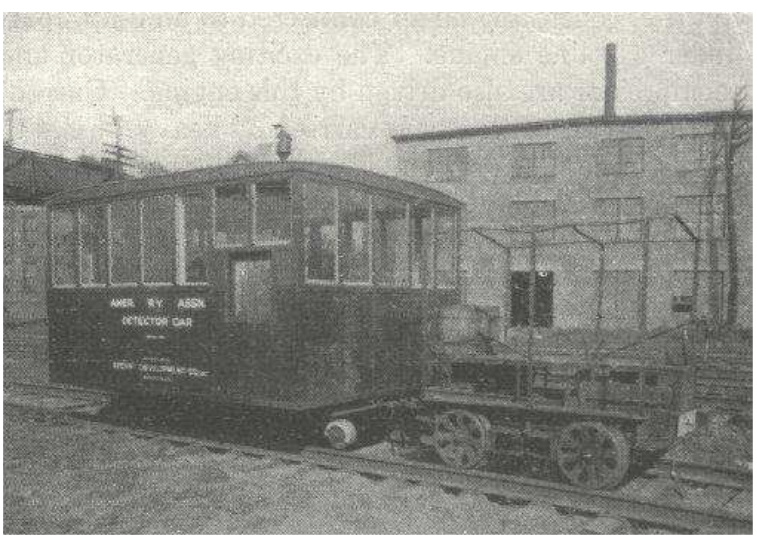

Рис. 4. Один з перших вагонів-дефектоскопів у світі, розроблений американцем Елмером Сперрі в 1928 році [8]

Дефектоскопічне обладнання розміщувалось на візку перед кабіною, а оператор та записувальний пристрій - в кабіні. Функціональну схему даного дефектоскопа подано на рис. 5.

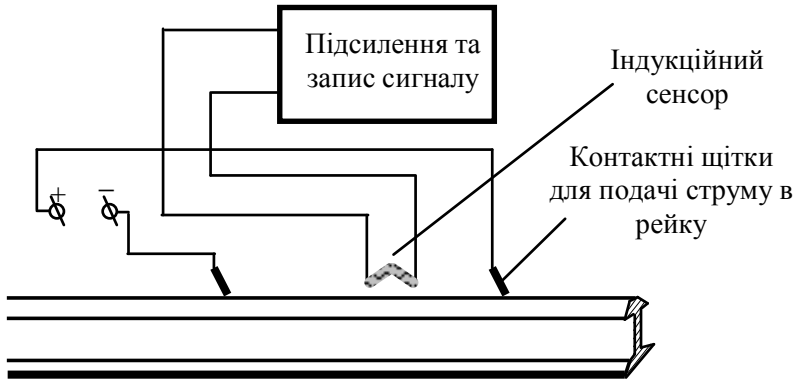

Рис. 5. Функціональна схема вагона-дефектоскопа, розробленого Елмером Сперрі [8]

Намагнічування рейок відбувалось пропусканням через рейку постійного струму значної величини (до 3.5 кА) при напрузі 0.8 В. Давачі були представлені двома котушками індуктивності (по одній на кожну нитку колії). Робоча швидкість дефектоскопа не перевищувала 20 км/год.

Після успішного впровадження дефектоскопа в експлуатацію в 1928 році Елмер Сперрі заснував фірму "Sperry Rail Service" [9], яка існує і дотепер.

B наступних дефектоскопах "ARA" як система намагнічування використовувались потужні П-подібні електромагніти постійного струму, а давачі розміщувались позаду другого (за напрямом руху) полюсу електромагніту, тобто за межами його магнітного поля (режим роботи за методом залишкової намагніченості рейок).

На залізницях США та Франції також набув значного поширення вагон-дефектоскоп фірми “Teleweld", який працював в режимі прикладеного магнітного поля, яке створювалось (для кожної нитки коліі) трьома потужними стержневими електромагнітами. Давач дефектоскопа складався 3 трьох пар локальних котушок індуктивності. Особливістю цього дефектоскопа було використання додаткового електромагніту, який створював слабке змінне магнітне поле розмагнічування поверхневого шару рейки для зменшення кількості імпульсних сигналів, які відповідали безпечним поверхневим дефектам рейок. Даним вагоном-дефектоскопом виявлялись дефекти рейок (поза межами стикових накладок) при швидкості руху до 20 км/год.

У Росії перший магнітний вагон-дефектоскоп був випущений в 1933 році, він був розроблений винахідником Ф. М. Карповим.

У конструкції Ф. М. Карпова використовувалося контрольно-вимірювальне обладнання, яке включало [10]:

- пристрій намагнічування 3 котушками, жорстко закріпленими на осях колісних пар;

- магнітомеханічні пошукові давачі;

- пристрої індикації наявності дефекту у вигляді ламп;

- систему реєстрації сигналів від давачів у вигляді самописного апарату;

- пристрій для відмітки дефектного місця на рейці.

Струм в котушки намагнічування подавався за допомогою спеціального контактно-щіткового пристрою. Для живлення котушок та інших пристроїв використовувався дизель-генератор постійного струму потужністю 15.5 кВт. При цьому створювана магнітна індукція в рейці досягалася 1.5-2 Тл, що забезпечувало намагнічування рейок між полюсами системи намагнічування до стану насичення.

Як чутливі елементи використовувалися магнітомеханічні замикачі у вигляді трьох стрілкових індикаторів. Під впливом полів розсіювання дефектів стрілки поверталися і замикали контакти, до яких були підключені реле виконавчих кіл (ламп світлової сигналізації, самописного апарату, розприскувача фарби). Була можливість регулювати чутливість стрілок, що дозволяло налаштовувати їх таким чином, щоб перша реагувала тільки на дефекти 3 площею ураження до $25 \%$ перерізу головки рейки, друга - від 25 до $50 \%$ і третя - на дефекти 3 площею більше 50 \% - свого роду праобраз автоматичного класифікатора дефектів.

Все обладнання розміщувалося на двох дрезинах. Перша служила як тягова і на ній було встановлено обладнання електроживлення. На другій розміщувалося контрольно-вимірювальне обладнання. Головна відмінність комплексу Ф. М. Карпова від аналогічних зарубіжних систем полягала в тому, що давачі працювали в активному полі, а не за методом залишкового намагнічування. Швидкість такого комплексу в робочому режимі становила до 20 км/год. Ця обставина зумовила його значне поширення і до 1937 року в Росії вже експлуатувалося чотири магнітних вагони конструкції Ф. М. Карпова. За їх 
допомогою щорічно перевірялося близько 2000 км колії і були виявлені сотні дефектних рейок. В автодрезині Ф. М. Карпова [10] при збільшенні швидкості більше 5-10 км/год на деяких ділянках колії зростав рівень шумів, що унеможливлювало подальший контроль стану рейок.

Перші діагностичні системи Елмера Сперрі i Карпова привели в подальшому до швидкого удосконалення мобільних засобів магнітної дефектоскопії залізничних рейок. В результаті численних досліджень, проведених в багатьох країнах, сформувався окремий метод швидкісної магнітної діагностики залізничних рейок, який дістав назву магнітодинамічний метод (МДМ).

Магнітодинамічний метод (МДМ). Цей метод, відомий також як Magnetic Flux Leakage (MFL) «витік магнітного потоку» або «розсіювання магнітного потоку», на даний час використовується у Великобританії, Ірані, США та в країнах бувшого Радянського Союзу для виявлення і характеристики дефектів сталевих канатів, трубопроводів, залізничних рейок, резервуарів та інших промислових об'єктів довготривалої та інтенсивної експлуатації [11]. Вимірювання двох компонент магнітного поля розсіювання: вертикальної (перпендикулярної до досліджуваної поверхні) та поздовжньої (паралельної до прикладеного поля) використовується в системах МДМ [12, 13]. Але застосування тільки двох компонент поля розсіювання буває малоефективним, особливо у тих випадках, коли форма досліджуваного об'єкту або дефекту по відношенню до прикладеного поля є довільною. Для цього вже потрібна реєстрація всіх трьох компонент поля, тобто виникає потреба у розв'язанні тривимірної задачі.

В 50-60-х роках на залізницях Радянського Союзу 3'явились магнітні вагони-дефектоскопи (МВД), які були розроблені колективами спеціалістів ВНДІЗТ та УралФТІ та дозволяли виявляти поперечні тріщини (коди дефектів 20 та 21 [14, 15] 3 площею дефекту головки рейки від $25 \%$ і глибиною залягання до 4 мм) на швидкості до 70 км/год. Крім того, ці МВД надійно виявляли поперечні і поздовжні тріщини в рейках (коди дефектів 24, 25, 27, 30B та 30Г), а також зломи рейок (коди 70, 74, 79) [14, 15].

Система намагнічування таких МВД складалась 3 двох потужних електромагнітів (по одному на кожну залізничну рейку), що утворювали на контрольованій ділянці рейки магнітний потік для виявлення дефектів. При магніторушійній силі (м.р.с.) котушок П-подібної намагнічувальної системи в 40 кА та номінальній величині зазора між полюсами та рейкою 8-12 мм в ній утворюється магнітний потік від 7 до 10 мВб [16]. Значна частина утвореного намагнічувальною системою магнітного потоку замикається через вагонні конструкції та повітря і утворює потік розсіювання, який дозволяє отримати дефектограму рейкової колії.
Давач сигналу розміщений на пошуковій лижі, яка ковзає по поверхні головки рейки в процесі руху вагона-дефектоскопа, реєструючи зміну магнітного потоку над поверхневим або підповерхневим дефектом. Запровадження комп'ютерної реєстрації сигналів магнітного контролю [17] дозволило підвищити роздільну здатність системи і виявляти дефекти в зоні зварних та болтових стикових з'єднань рейок (дефекти типів 26.3 і 21.1), які раніше не фіксувались МВД при записі сигналів на магнітну плівку або на паперову стрічку.

У 70-80-ті роки в СРСР експлуатувалось близько сотні МВД [14], які контролювали безпеку руху поїздів, своєчасно виявляючи небезпечні дефекти в рейках до досягнення ними критичних розмірів у найбільш несприятливих погодних умовах (при температурі нижче $-30{ }^{\circ} \mathrm{C}$ та високому сніговому покриві), коли інші методи часто були непрацездатними [18]. Дотепер, за даними [19], у країнах, що входили до складу бувшого Радянського Союзу, експлуатуються близько ста МВД різних модифікацій та комплектації. Їх технічні можливості дають змогу в найрізноманітніших кліматичних умовах контролювати верхню частину головки рейки на глибину до 7-8 мм за швидкостей від 20 до 80 км/год.

Досвід експлуатації вагонів-дефектоскопів виявив також їх основні недоліки:

a) наявність повітряного зазора між полюсами магніту та рейкою. Збільшення цього проміжку задля безпеки руху до 20-23 мм приводить до значного послаблення магнітного потоку в рейці. При цьому за рахунок збільшення потоку розсіювання чітко фіксуються всі конструктивні елементи рейкової колії i в оператора створюється помилкове враження нормального функціонування комплексу, в той же час як не фіксуються сигнали від внутрішніх дефектів рейок, які доступні МДМ;

б) в класичних вагонах-дефектоскопах міжполюсна віддаль складає всього 80 см (наприклад, у львівському вагоні-дефектоскопі № 442 міжполюсна віддаль складає близько 1 м) (рис. 6). Така міжполюсна віддаль забезпечує достатнє промагнічування рейки в статичному режимі [20]. Однак при великих експлуатаційних швидкостях, порядку 60-70 км/год, магнітне поле не встигає промагнітити рейку на достатню глибину за час проходження намагнічувальної системи над іiі дефектною ділянкою. Це пов'язано зі значним зростанням вихрових струмів в рейці при збільшенні швидкості переміщення дефектоскопічної системи;

в) значні габарити електромагнітів системи намагнічування рейок, які повністю займають міжколісний простір індукторного візка, та їх енергоємність. Споживана потужність електромагнітів складає приблизно 15 кВт. 
І Н Ф О Р М А Ц І Й О - К Е Р У Ю Ч І С И С Т Е М И Н А 3 А Л І 3 Н И Ч Н О М У Т Р А Н С П О Р Т І

Усунення чи мінімізація впливу цих недоліків, на думку авторів статті [20], може відбуватись таким чином:

а) громіздка та енергозатратна намагнічувальна система на основі електромагнітів повинна бути замінена намагнічувальною системою на основі сучасних постійних магнітів через колісні пари індукторного візка [21, 22];

б) однокомпонентна приймальна система на основі інтегральних індукційних сенсорів повинна бути замінена трикомпонентною багатоканальною системою на основі точкових сенсорів Холла, що дозволить реалізувати матричні багатоканальні i компонентні рейкові сенсори;

в) повинна бути розроблена нова апаратнопрограмна частина діагностичної системи збору, передавання та аналізу дефектоскопічної інформації, яка забезпечить оброблення багатоканальної дефектоскопічної інформації в режимі реального часу.

Основні переваги мобільної МДМ дефектоскопії, у порівнянні з ультразвуковою, такі [20]:

1. Можливість безконтактного контролю рейок 3 зазором 8-10 мм до поверхні рейки.

2. Надійність контролю в широкому діапазоні температур повітря i при великій швидкості переміщення вагона-дефектоскопа.

3. Чітке відображення на дефектограмах всіх регулярних структурних елементів рейкової колії (болтові з'єднання, ізольовані і зварні стики, шпальні підкладки, хрестовини, контррейки, стрілочні переводи тощо), що забезпечує однозначне встановлення положення дефекту.

4. Відпрацьовані методи розшифровки результатів контролю за типами дефектів.

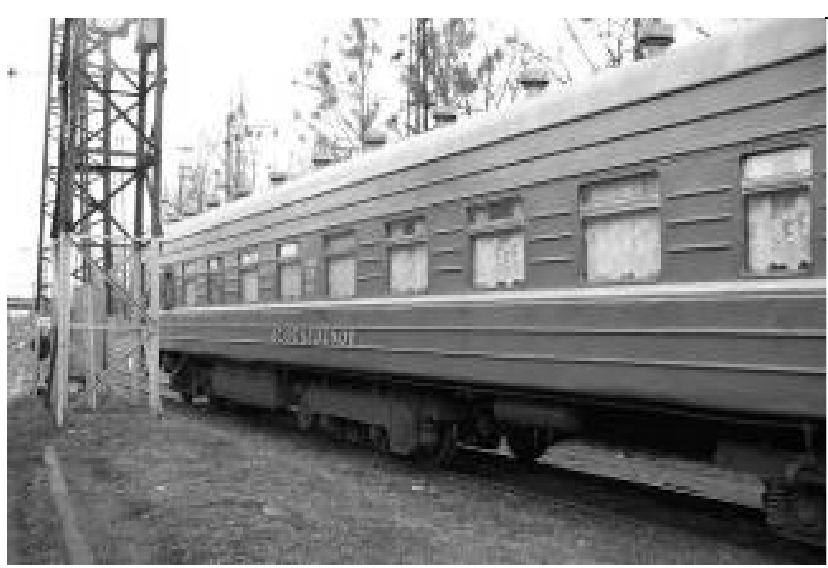

a

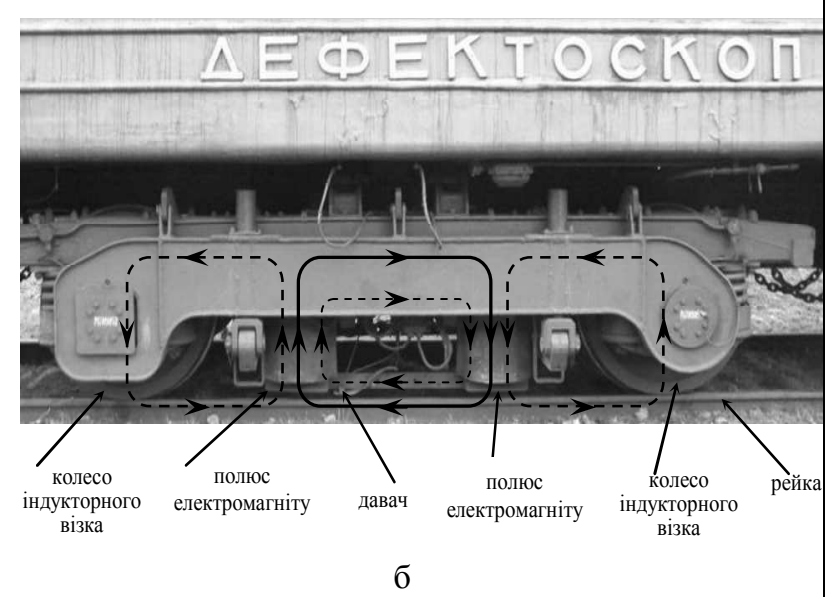

6

Рис. 6. Львівський вагон-дефектоскоп № 442 для МДМ діагностики дефектів рейок [20]: а) загальний вигляд вагона-дефектоскопа; б) вигляд індукторного візка і намагнічувальної системи вагона-дефектоскопа

Технологія вимірювання поля змінного струму (ВПЗС). Ця технологія відома в англомовній літературі під назвою Alternative Current Field Measurement (ACFM) - «вимірювання поля від змінного струму».

Технологія вимірювання поля змінного струму спочатку розвивалась як безконтактна версія технології вимірювання падіння потенціалу від змінного струму для точного вимірювання глибини тріщин на поверхні зварки під водою в середині 1980-х років. Перші комерційні системи ВПЗС були виготовлені у 1991 році для підводного огляду зварних конструкцій у відкритому морі. 3 тих пір ця технологія поширилась у багатьох різних застосуваннях як під водою, так і на поверхні землі. Зокрема, це системи для огляду нарізних з'єднань у гірничорудній промисловості, системи альтернативної інспекції у нафтогазовій промисловості, автоматизовані системи огляду накладок коксового барабана та сучасні складні напівавтоматичні матричні системи для огляду високошвидкісних залізничних колій [3, 23-30].

Технологія ВПЗС являє собою електромагнітний метод контролю, який дозволяє виявляти та класифікувати поверхневі тріщини в металах. Основою технології є змінний, локально рівномірний індукований струм, що протікає в досліджуваному об'єкті. Типовою робочою частотою є частота порядку $10^{4}$ Гц. Такий струм протікає в поверхневому шарі будь-якого провідника i не залежить від його геометрії. При відсутності дефектів електричний струм буде однорідним, але якщо поверхнева тріщина $\epsilon$, однорідний струм змінюватиметься та протікатиме навколо кінців і внизу граней тріщини. Магнітне поле над поверхнею металу, яке пов'язане з цим струмом, також зміниться.

Технологія ВПЗС використовує індукований, а не інжектований струм, підтримуючи постійні силу та напрямок струму. Це головна відмінність цієї технології від звичайних технологій вихрових струмів. Вимірюючи складові утворених поверхневих зв'язаних 
магнітних полів та порівнюючи результати 3 теоретично прогнозованими, ВПЗС дає можливість визначити довжину та глибину дефекту, не маючи необхідності в калібруванні на еталонах. При цьому забезпечується можливість як виявлення, так i класифікації поверхневих тріщин в металах. Дослідження не потребує ніякого електричного чи магнітного контакту давача 3 досліджуваним об'єктом та може бути застосоване без видалення покриття поверхні (фарба, лак, мастило, іржа тощо) чи бруду. При даному методі рівень сигналу, при віддаленні давача від зразка, зменшується пропорційно квадрату віддалі, а не кубу, як у давачів на вихрових струмах. За рахунок цього сигнали зменшуються відносно повільно, навіть коли давач відривається від поверхні на віддаль більше 5 мм. Таким чином, шорсткість поверхні або велика товщина непровідного покриття створюють менше проблем, ніж при звичайному контролі за допомогою давачів на вихрових струмах, яким необхідно бути розміщеними на віддалі менше 2 мм від досліджуваної поверхні.

Рис. 7, а демонструє силові лінії однорідного змінного струму, який протікає під прямим кутом до площини дефекту, та систему координат для визначення напрямків компонент індукції магнітного поля.
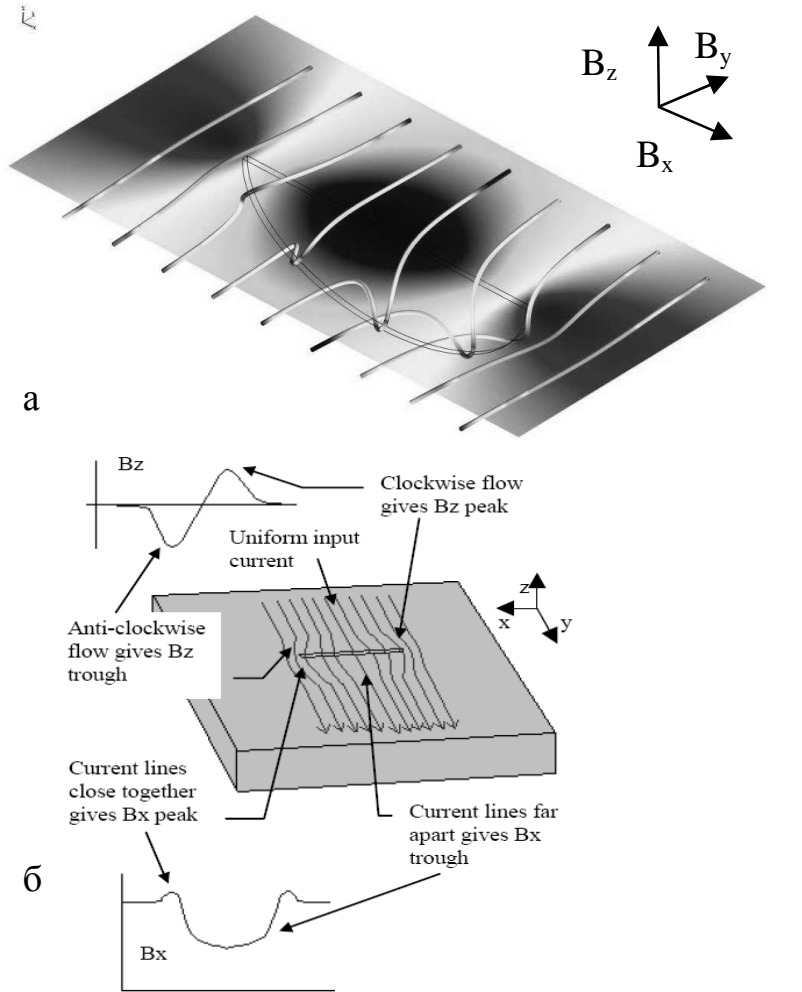

Рис. 7. Фізичні принципи технології ВПЗС [1, 3]: a) однорідний змінний струм, що протікає навколо дефекту; б) компоненти $\mathrm{B}_{\mathrm{x}}$ та $\mathrm{B}_{\mathrm{z}}$ індукції магнітного поля, створюваного змінним струмом
Компонента індукції магнітного поля, паралельна до поверхні та перпендикулярна до струму (позначена $\mathrm{B}_{\mathrm{x}}$ ), пропорційна густині поверхневого струму, яка зменшується в центрі тріщини та збільшується на іiі краях, оскільки електричний струм протікає навколо тріщини. Величина зменшення $\mathrm{B}_{\mathrm{x}}$, таким чином, відображає глибину дефекту. Компонента поля, перпендикулярна до поверхні (позначена $\mathrm{B}_{\mathrm{z}}$ ), створюється циркулюючими потоками струму. Вони знаходяться навколо країв тріщини (за годинниковою стрілкою на одному кінці та проти годинникової стрілки - на іншому), що формує додатні та від'ємні рівні сигналу. При цьому віддаль між максимальним та мінімальним сигналами $\mathrm{B}_{\mathrm{z}}$ відповідає довжині тріщини. Для того щоб оцінити розміри дефекту, достатньо тільки два виміри, якими $є$ відсоток зменшення $\mathrm{B}_{\mathrm{x}}$ в центрі тріщини та віддаль між розташуванням максимального та мінімального значення компоненти $\mathrm{B}_{\mathrm{z}}$ (рис. 7, б).

Для керування обладнанням та виведення результатів на дисплей використовується стандартний ПК. Графік зліва на рис. 8 показує типові необроблені дані з країв тріщини $\left(\mathrm{B}_{\mathrm{z}}\right)$ та іiі глибини $\left(\mathrm{B}_{\mathrm{x}}\right)$, зібрані датчиками від давача керованого вручну. Права сторона рисунку 8 демонструє ті самі дані, які подано у вигляді годографа, у якому $\mathrm{B}_{\mathrm{x}}$ поданий в залежності від $\mathrm{B}_{\mathrm{z}}$. При наявності дефекту на екрані відображається петля у вигляді кардіоїди і оператор шукає відмінності іï форми від типової, щоб вирішити, наявна тріщина чи ні. Всі дані зберігаються системою і $\epsilon$ доступними для подальших аналізу та контролю, а також формування звітності.

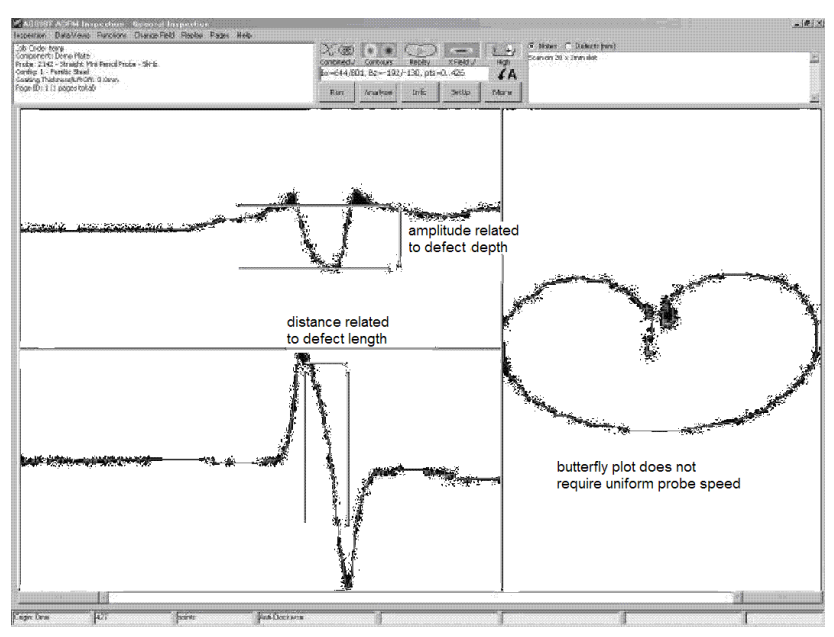

Рис. 8. Типовий сигнал у ВПЗС, спричинений дефектом [3]

Технологія ВПСЗ знайшла також своє застосування та вдосконалення і в залізничній галузі для перевірки вагонів, колісних пар та рейок. 
І Н Ф О Р М А Ц Й Н О - КЕ Р У Ю Ч І С И С Т Е МИ Н А З А Л І З Н И Ч Н О М У Т Р А Н С П О Р Т І

Огляд вагонів є порівняно простий, оскільки це звичайні зварні металеві конструкції, вкриті фарбою, а швидкість огляду, як правило, не є критичною. Колісні пари в більшій мірі впливають на безпеку руху, а тому потребують більш точних та об'ємних випробувань, які гарантують достовірність результатів [3, 25]. Дослідження показали, що ВПЗС перевершив деякі інші методи (наприклад, метод огляду намагніченими частинками (ОНЧ)), особливо 3 точки зору достовірності результатів. Рамковий проект 7 R\&D SAFRAIL, що фінансувався EC (грантова угода № 218674), призвів до розробки найсучасніших зразків масивів давачів ВПЗС на даний час. Рис. 9, а демонструє портативний пристрій, який був розроблений для перевірки колісних пар, та приклад результатів дослідження штучних дефектів. Це пристрій складається з сенсорного блока, що містить чотири пари давачів, які відповідають за формою радіусу на фланці колеса, і чотирнадцять сумісних плунжерів, кожен з яких має додаткову пару давачів для огляду основної частини колеса, що підходить навіть для значного зносу колеса без зняття давачів. В ході випробувань на раніше пошкоджених колісних парах дана система досягла 84 \% виявлення дефектів у порівнянні з 44 \% їх виявлення методом ОНЧ.

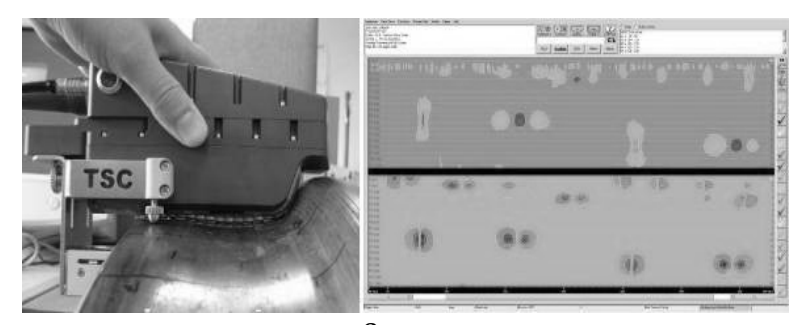

a
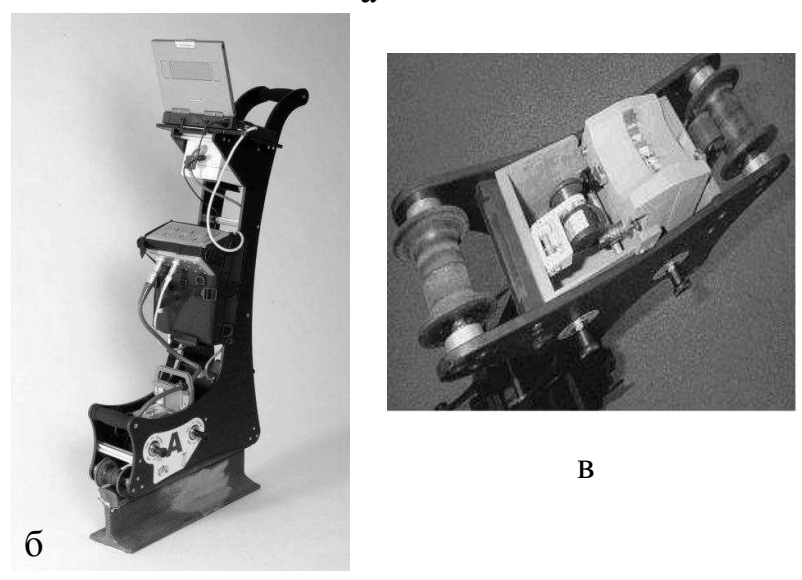

B

Рис. 9. Техніка ВПЗС $[1,3]$

Слідом за цими розробками увагу було привернуто до калібрування тріщин на рейках від ПКВ. Руйнування рейок від ПКВ при розтріскуванні, особливо на згинах, було основною проблемою у Великобританії в 1990-х роках. Контроль зазвичай здійснювався візуальним оглядом та за допомогою портативних ультразвукових інспекційних пристроїв. Візуальне обстеження не дає ніяких вказівок на глибину виявлених дефектів, також існувало обмеження стосовно того, що ультразвукові давачі не могли визначити розміри найглибшого дефекту, якщо він був тісно оточений більш дрібними.

Дефекти ПКВ мають дуже відмінну морфологію порівняно зі стандартними тріщинами втоми, для яких було розроблено ВПЗС. Вони, як правило, нахилені лише на $30^{\circ}$ або близько того від поверхні, але потім можуть змінювати напрямок, щоб вирости в напрямку поверхні, що призводить до втрати частини поверхні рейки, або ж навпаки можуть швидко формуватися вниз через рейку, що веде до ії розриву. На доповнення до цього, фронт тріщини часто буде ширшим під поверхнею, ніж на поверхні, і глибина тріщини буде більшою в порівнянні з їі розмірами на поверхні. Всі ці фактори означають, що теоретична модель калібрування, створена у 1980-х, не працює для тріщин ПКВ. Для подолання цього проводились тривалі випробування 3 калібрування за допомогою рейки 3 реальними тріщинами ПКВ. Результати калібрування за допомогою нової процедури калібрування були згодом порівняні 3 іншими дефектними рейками i загалом було досягнуто узгодження $[3,26]$.

Було створене спеціальне програмне забезпечення, що включає новий алгоритм калібрування. Це програмне забезпечення також включало автоматичне визначення та повідомлення про найглибший дефект, який було знайдено на даному відрізку рейки. Масив давачів ВПЗС, який за формою є подібним до профілю рейки, був прикріплений до портативної діагностичної системи (див. рис. 9, в), яка також містила модифікований високошвидкісний пристрій Amigo та ноутбук. Це абсолютно автономний пристрій, який здатний до проведення 8-годинної незалежної перевірки рейок [3].

При збільшенні частоти дискретизації до 50 кГц портативна діагностична система досягла швидкості сканування $0,75 \mathrm{~m} / \mathrm{c}$ (приблизно 2-3 км рейки можуть бути перевірені протягом години) (рис. 9, б). Слід підкреслити, що зібрані дані є достатніми для того, щоб не тільки виявити дефект, а й за допомогою спеціального програмного забезпечення визначити його важкість [1].

В даний час у Великобританії (компанії Bombardier Transportation, TSC та Network Rail) проводяться подальші дослідження, спрямовані на прискорення пропускної спроможності даних та роботи систем ВПЗС на високій швидкості, що дозволяє розгортати ВПЗС на шляхових транспортних засобах, таких як дорожньо-залізничні автомобілі (автомотриси) та випробні поїзди, що рухаються зі швидкістю від 15 до 100 км/год.

Промисловістю випускаються давачі ВПЗС у стандартній формі олівця та у вигляді 
багатоелементних масивів давачів. Давачі у формі олівця можуть виявити поверхневі дефекти, розміщені в будь-якій орієнтації. Проте, для того щоб визначити розміри дефекту, він повинен знаходитись в діапазоні 0-30 давача. Цей недолік подоланий в масивах давачів ВПЗС шляхом використання різнонапрямлених магнітних полів та додаткових давачів, для аналізу цих полів у різних напрямках. Це особливо корисно в тих ситуаціях, де орієнтація тріщини невідома або змінна [3].

Візуально-вимірювальні та оптичні методи мобільної діагностики

До недавнього часу візуальний огляд проводився тільки досвідченим персоналом, який проходить уздовж залізничної колії і фізично шукає дефекти. Це потенційно небезпечна практика, хоча досить часто використовується фірмами-операторами залізничного транспорту. За останні декілька років були реалізовані різні системи відеоспостереження на основі візуальних камер для застосування на залізницях [1]. Вони можуть бути класифіковані відповідно до їх функціонального призначення на чотири основні групи:

а) системи візуального контролю колії;

б) системи візуального огляду поїзда;

в) системи технічного обслуговування та експлуатації;

г) системи, пов'язані 3 пасажирськими перевезеннями.

Концепція автоматизованих візуальних систем заснована на використанні високошвидкісної камери, здатної захоплювати відеозображення рейкової колії, коли поїзд рухається над нею. Захоплені зображення потім автоматично аналізуються за допомогою програмного забезпечення для аналізу зображень. Аналіз програмного забезпечення заснований на ідентифікації об'єктів або дефектів, виявлених за допомогою методів крос-кореляції та вейвлетперетворень, в той час як дані класифікуються 3 використанням схеми контрольованого навчання та теорії нейронних мереж. Розпізнавання об'єктів 3 використанням технології навчання на зразках пов'язане 3 обчислювальними проблемами. Для досягнення режиму реального часу загальна тривалість обчислень повинна бути невеликою. При необхідності виявити більш дрібні об'єкти, такі як дефекти на поверхні рейки, роздільна здатність захопленого відеозображення має бути високою, щоб забезпечити достовірні дані для аналізу. Однак, при підвищенні роздільної здатності відеозображення підвищується також i кількість отримуваних даних, a, отже, i збільшується тривалість обчислення, необхідна для завершення аналізу. В результаті швидкість огляду повинна бути скоригована так, щоб відповідати швидкості аналізу даних.
Автоматизовані системи візуального контролю колії можуть бути використані для контролю та вимірювання профілю головки рейки та відсотка іiі зносу, розриву колії, зміщення шпал, відсутності частини баласту (мінерального сипкого матеріалу між шпалами та земляною поверхнею), стану опорної плити при відсутності баласту, відсутності болтів кріплення та пошкодження поверхні тощо. Швидкість роботи цих систем може змінюватись від 60 до 320 км/год залежно від типу перевірки і необхідної роздільної здатності. Наприклад, перевірка для виявлення деформацій залізничних рейок може бути виконана набагато швидше, ніж для виявлення тріщин від ПКВ. Проте автоматизовані системи візуального контролю не забезпечують всієї інформації щодо наявності будь-яких внутрішніх дефектів i, отже, не можуть бути використані для повної заміни ультразвукового контролю.

У компаніï Société Nationale des Chemins de fer Français (SNCF), зокрема, проводять інспекцію високошвидкісними камерами по своїй мережі залізничних колій новим транспортним засобом «IRIS 320», який може досягати швидкості до 320 км/год. Ці перевірки проводяться кожні 15 днів, щоб виявити візуальні дефекти поверхні найбільш високошвидкісних ліній, а також основних ліній (швидкість $\geq 160$ км/год). На рис. 10 показаний принцип візуального огляду залізничних колій.

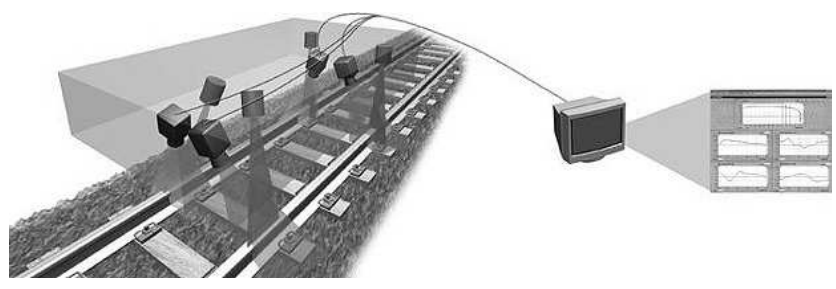

Рис. 10. Огляд рейкової колії з використанням візуальних камер [1]

Подібні системи розроблені також у Німеччині (Bildverarbeitungssysteme $\mathrm{GmbH}$ ) та Італії (MERMEC). Особливістю їх $є$ можливість забезпечити регулярний автоматизований візуальний огляд залізничних колій 3 точним та раннім виявленням дефектів та високою швидкістю обробки. Ці візуально-вимірювальні системи можуть бути використані як для перевірки всієї поверхні рейки, так і відсутності кріплень, шпал та баласту.

Гібридні системи мобільної діагностики дефектів залізничних колій

Останнім часом гібридні системи, засновані на одночасному використанні імпульсних давачів на вихрових струмах [31-35] і звичайних ультразвукових давачів, були введені в Німеччині, Нідерландах та в інших країнах для огляду високошвидкісних залізничних колій. Імпульсні давачі на вихрових струмах здатні точно виявляти тріщини середнього 
розміру ( 4 мм) і можуть працювати зі швидкістю до 72 км/год без істотних відмінностей в їх роботі. Проте продуктивність давачів на вихрових струмах у значній мірі залежить від рівномірності віддалі до поверхні, що означає, що деякі дефекти поверхні все ще можуть бути пропущені під час огляду. 3 цієї причини в даний час ведуться масштабні дослідження для розробки нового високошвидкісного обладнання гібридних систем мобільної діагностики дефектів залізничних колій, включаючи високошвидкісні камери, електромагнітні акустичні перетворювачі (ЕМАП), ультразвукові фазові антенні решітки (УФАР), ультразвукові лазери та багаточастотні давачі на вихрових струмах тощо [1].

На теренах колишнього СРСР також ведуться дослідження 3 розробки гібридних систем мобільної діагностики дефектів залізничних колій. Зокрема, в Білорусії ЗАТ “Гомельський ВС3" виготовляє суміщений вагон-дефектоскоп на базі нового типу пасажирського вагона (модель кузова 61-537.1) (рис. 11, а) [36].

В операторському приміщенні цього вагонадефектоскопа розміщуються: комп'ютерна апаратура, спеціалізований дефектоскопічний комплекс, апаратура керування ультразвуковим i магнітним інформаційними каналами та інше спеціалізоване обладнання. Живлення цього комплексу обладнання, а також дефектоскопічної намагнічувальної системи забезпечується дизель-електричним генератором потужністю 13 кВт.

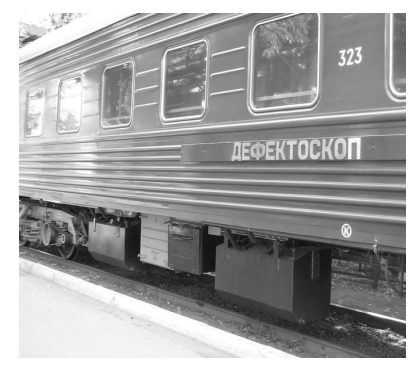

a

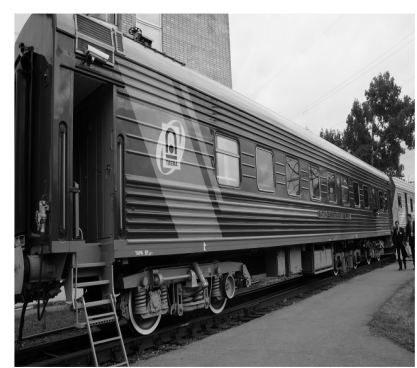

6
Рис. 11. Суміщені вагони-дефектоскопи [36 - 38]

Робоча швидкість вагона-дефектоскопа при контролі залізничної колії магнітним методом складає 60 км/год, а ультразвуковим методом - 40 км/год.

Російська фірма “ТВЕМА” (м. Москва) з 2009 року виготовляє вагони-дефектоскопи нового покоління ВД-УМТ-1 (рис. 11, б), які обладнані найновішими засобами ультразвукового та магнітного контролю (багатоканальний дефектоскоп «ЕХО-КОМПЛЕКС-2») [37]. При проведенні процедури контролю стану залізничних колій визначення дефектів проводиться трьома методами неруйнівного контролю ультразвуковим, магнітним та оптичним.
Магнітний метод дозволяє контролювати наявність дефектів рейок навіть при температурах $-50-+50^{\circ} \mathrm{C}$, оскільки робота ультразвукових дефектоскопічних систем $є$ утрудненою при температурі нижче $-30{ }^{\circ} \mathrm{C}$ через можливість замерзання контактної рідини на основі водно-спиртової суміші. Намагнічувальна система «МАРС» 3 потужним магнітним потоком забезпечує глибоке промагнічування рейок, що дозволяє виявляти дефекти на ранніх стадіях їх розвитку $[37,38]$.

Вагон-дефектоскоп оснащено спеціальним колісним візком 3 шарнірним вузлом для постійного контакту колісних пар та рейок, що забезпечує плавне переміщення на кривих ділянках та стрілочних переводах. Позиціонування ультразвукової лижі відносно поздовжньої осі головки рейки забезпечується не через механічний контакт з рейкою, а - безконтактним магнітним методом, що дає можливість:

- виключити механічний контакт центруючої системи 3 рейкою, що створює додаткові акустичні завади та знижує ресурс центруючої системи;

- мінімізувати залежність точності центрування від стану робочої поверхні головки рейки;

- запобігти порушенню акустичного контакту, що обумовлено попаданням снігу між рейкою та ультразвуковою лижею;

- забезпечити проходження будь-яких стрілочних переводів;

- підвищити швидкість контролю.

Камери лінійного відео 3 високою роздільною здатністю та системою освітлення реалізують систему візуального визначення та вимірювання дефектів на поверхні рейок і елементів їх кріплення («СВОД-2»), яка автоматизує та спрощує монотонний процес неперервного оптичного контролю та дозволяє виключити “людський фактор”, що зменшує ймовірність помилок.

32015 року фірма "ТВЕМА" почала випуск ще більш сучасних вагонів-дефектоскопів ВД-УМТ-2 [38], які мають такі переваги перед ВД-УМТ-1:

- використання вдосконалених засобів та систем комплексної неруйнівної діагностики (ультразвукової, магнітної, візуально-вимірювальної та оптичної);

- можливість реалізації загальної швидкості контролю до 60 км/год;

- розширений кліматичний діапазон експлуатації тощо.

Крім вищезгаданих систем контролю, у цьому вагоні-дефектоскопі застосовано високошвидкісну систему вимірювання параметрів залізничної колії «СОКОЛ-2» і для отримання та обробки даних про стан елементів колії у вагоні використовується реєструючий комплекс та спеціалізоване програмне забезпечення «ИНТЕГРАЛ», яке забезпечує: 
І Н Ф О Р М А І ЙН О-КЕ Р У Ю Ч С ИС Т Е И Н А З А Л І Н ИЧН О М У Т Р АН С П О Р Т І

- реєстрацію даних від дефектоскопічного обладнання про стан елементів залізничної колії, а також про поточні координати колії та швидкість руху вагона-дефектоскопа;

- архівацію та зберігання документів контролю всіх діагностичних систем.

Система автоматизованої обробки результатів контролю «АСТРА» дозволяе здійснювати автоматизовану розшифровку типів дефектів в рейках, а також інших додаткових параметрів технології неруйнівного контролю.

Також тут реалізована додаткова система оглядового спостереження за станом елементів колій.

В Україні, у Інституті телекомунікацій, радіоелектроніки та електронної техніки Національного університету "Львівська політехніка" науковою групою вже тривалий час ведуться дослідження у галузі МДМ дефектоскопії 3 використанням для натурних експериментів львівського МВД № 442.

Для лабораторних досліджень МДМ діагностики залізничної колії використовується спеціально розроблений в інституті експериментальний стенд, в якому первинне магнітне поле в відрізках дефектних рейок збуджується потужними постійними магнітами $[39,40]$. Зовнішній вигляд експериментального стенда показаний на рис. 12.

В результаті проведених досліджень створений робочий макет принципово нової багатоканальної компонентної інформаційно-діагностичної системи, яка реалізує МДМ діагностики залізничних рейок на основі сенсорів Холла [41 - 45].

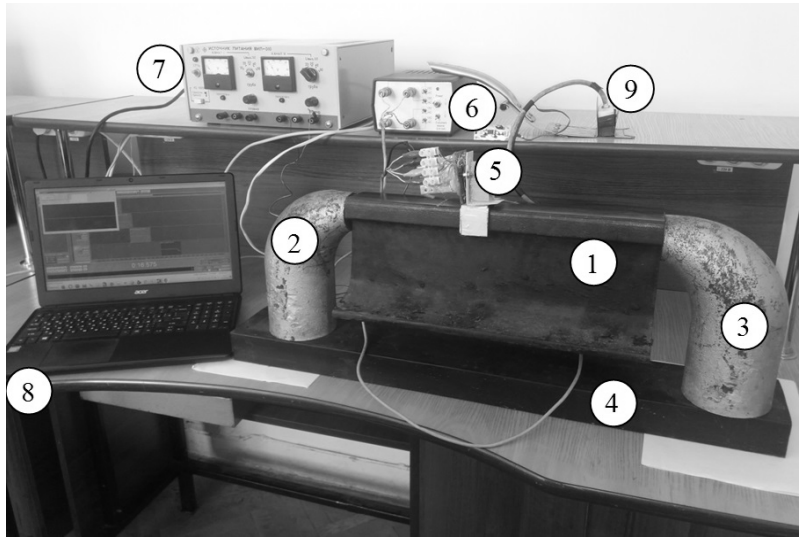

Рис. 12. Експериментальний стенд для дослідження сигналів дефектів відрізків рейок: 1 - відрізок рейки 3 дефектом, що досліджується; 2, 3 - полюси постійних магнітів; 4 - ярмо-магнітопровід, що з'єднує полюси постійних магнітів; 5 - пересувний візок з сенсорами Холла і канальними підсилювачами; 6 - аналоговоцифровий перетворювач (АЦП); 7 - блок живлення; 8 - комп'ютер; 9 - індукційний інтегральний сенсор на пошуковій лижі від магнітного вагона-дефектоскопа

\section{Висновки}

Аналіз сучасних методів та засобів дефектоскопії залізничних колій дозволяє зробити висновок, що незважаючи на значні досягнення в цій галузі, залишається можливість їх подальшого вдосконалення.

Зокрема, в галузі магнітодинамічного методу дефектоскопії не вичерпані можливості щодо збільшення швидкості при проведенні діагностики, яка в значній мірі залежить від параметрів намагнічувальної системи і іiі здатності промагнітити рейку. Цьому сприяє збільшення бази між полюсами магнітів 3 можливим контролем положення пошукових сенсорів над поверхнею рейки при поворотах.

Для надійного виявлення та розрізнення сигналів від дефектів необхідно збільшити інформативність дефектоскопічної системи шляхом використання багатоканальних та багатокомпонентних сенсорів. Зокрема авторами було встановлено, що вертикальна складова магнітного поля розсіяння дефекту також $є$ інформативною, a їх сумісний аналіз підвищує надійність виявлення i розрізнення дефектів. Подальший значний успіх в питаннях оперативного виявлення складних тріщин 3 нестандартною "об'ємною геометрією" може бути досягнутий при реєстрації всіх трьох компонент магнітного поля розсіяння дефекту МДМ - (3D magnetic field sensing for magnetic flux leakage defect characterization).

Застосування багатоканальних систем опрацювання дефектоскопічної інформації 3 реєстрацією 3-х компонент сигналу дефекту разом 3 сумісним аналізом форми і амплітуди сигналів по кожному каналу дозволить однозначно визначити орієнтовні розміри дефекту, локалізувати його розташування в межах перетину головки рейки i класифікувати дефект, що приведе, в цілому, до суттєвого підвищення ефективності інформаційнодефектоскопічної системи, в тому числі до виявлення дефектів рейок на ранніх стадіях їх зародження i встановлення ступеня їх небезпеки.

Збільшення кількості дефектоскопічної інформації суттєво ускладнює роботу операторів вагонівдефектоскопів, яка є достатньо напружена і може стати причиною збільшення кількості пропущених дефектів. Це ставить завдання 3 розроблення спеціальних програмних засобів для автоматичного виявлення та розрізнення сигналів дефектів в режимі реального часу. Алгоритми виявлення та розрізнення дефектоскопічних сигналів можуть бути реалізовані на базі сумісного використання при аналізі сигналів дефектів вейвлет-перетворень та технології нейронних мереж при наявності бібліотеки реальних дефектоскопічних сигналів.

Внаслідок ширшого застосування і впровадження пропонованих заходів діагностики дефектів залізничних колій очікується підвищення 
достовірності та оперативності виявлення сигналів дефектів в процесі сканування при збільшенні швидкості руху вагона-дефектоскопа.

\section{Список використаних джерел}

1. INNOTRACK (Innovative Track Systems) D4.4.1 Rail Inspection Technologies [Text] // Integrated Project no. TIP5-CT-2006-031415. - University of Birmingham (Great Britain), 2008. - 42 p.

2. Карпаш, А. М. Аналіз відомих методів контролю фізико-механічних характеристик металу [Текст] / А. М. Карпаш // Нафтогазова енергетика: всеукр. наук.-техн. журн. - Івано-Франківськ : ІФНТУНГ. - 2012. - № 1(17). - С. 70-82.

3. Lugg, M. The First 20 years of the A.C. field Measurement Technique [Text] / M. Lugg // World Conference on Non-Destructive Testing: XVIII Int. Conf., 16-20 April 2012: Proceedings. - Durban (South Africa), 2012. - Vol. 1. - P. 494-500.

4. Гурвич, А. К. Неразрушающий контроль рельсов при их эксплуатации и ремонте [Текст] / А. К. Гурвич, Б. П. Довнар, В. Б. Козлов [и др.]; под ред. канд. техн. наук А. К. Гурвича. - М. : Транспорт, 1983. - 318 с

5. Lesiak, P. Nowa inteligentna aparatura ultradzwiekowa do badania szyn w torze [Tekst] / P. Lesiak, P. Gołabek, T. Ciszewski, D. Wieczorek, P. Bojarczak, A. Korneta, B. Rojek // Zeszyty Problemowe z XXIX Krajowej Konferencji Badan Nieniszczacych w Krynicy. - Warszawa, 2000. Zeszyt № 5. - S. 135-142.

6. Lesiak, P. Automatyzacja badan defektoskopowych szyn na szlaku kolejowym [Tekst] / P. Lesiak // Problemy Kolejnictwa. - Warszawa, 2001. - № 134. S. 105-121.

7. Clark, R. Ultrasonic characterisation of defects in rails [Text] / R. Clark, S. Singh, C. Haist // Insight. - 2002. - Vol. 44. - № 6. - P. 341-347.

8. Rail Inspection [Електронний ресурс]. - Режим доступу: http://www.ndeed.org/AboutNDT/SelectedApplications/RailInspectio n/RailInspection.htm.

9. Sperry [Електронний ресурс]. - Режим доступу: http://www.sperryrail.com.

10. Магнитные дефектоскопы изобретателя Ф. М. Карпова [Текст]. - М.: ВНТМ, 1939.

11. Wilson, J. W. 3D magnetic field sensing for magnetic flux leakage defect characterisation [Text] / J. W. Wilson, G. Y. Tian // Insight. - 2006. - Vol. 48. - № 6. - Р. 357-359.

12. Нічога, В. О. Компонентні давачі для магнітної діагностики технічного стану рейок залізничної колії [Текст] / В. О. Нічога, П. Б. Дуб, І. В. Сторож // Інформаційно-керуючі системи на залізничному транспорті. - 2014. - № 3. - С. 34-43.
13. Антипов, А. Г. Автоматизация анализа сигналов магнитодинамического контроля рельсов [Текст] / А. Г. Антипов, А. А. Марков // В мире неразрушающего контроля. - 2014. - № 2(64). C. 25-30.

14. Класифікація та каталог дефектів і пошкоджень елементів стрілочних переводів на залізницях України. ЦП-0284. - затв. наказом Укрзалізниці від 27.02.2013 № 050-Ц/од [Текст] / М-во інфраструктури України, Держадміністрація залізничного транспорту України, Укрзалізниця, Головне управління колійного господарства; розроб. В. В. Рибкін [та ін.]. - К. : Інпрес, 2013. C. 1-108.

15. Класифікація та каталог дефектів і пошкоджень рейок на залізницях України. ЦП-0285. - затв. наказом Укрзалізниці від 27.02.2013 № 050-Ц/од [Текст] / М-во інфраструктури України, Держадміністрація залізничного транспорту України, Укрзалізниця, Головне управління колійного господарства; розроб. В. В. Рибкін [та ін.]. - К. : Інпрес, 2013. - С. 109-194.

16. Марков, А. А. Магнитодинамический метод контроля рельсов [Текст] / А. А. Марков, А. Г. Антипов // В мире неразрушающего контроля. - 2012. - № 3(57). - С. 66-71.

17. Халилев, П. А. Рождение рельсовой дефектоскопии [Текст] / П. А. Халилев // Дефектоскопия. - 1999. - № 12. - С. 73-82.

18. Кононов, О. А. Дефектоскопический комплекс магнитного вагона-дефектоскопа [Текст] / О. А. Кононов, В. В. Осипов, А. А. Маркович [и др.] // Путь и путевое хозяйство. - 2000. - № 5. C. 23-25.

19. Воробьев, В. Н. Переход к новому качеству неразрушающего контроля рельсов [Текст] / В. Н. Воробьев, Е. А. Шур // Путь и путевое хозяйство. - 2013. - №10. - С.24-26.

20. Нічога, В. О. Магнітодинамічний метод діагностики залізничної колії i напрями його модернізації [Текст] / В. О. Нічога, І. Н. Прудиус,

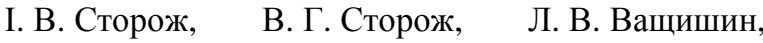
П. Б. Дуб // Вісник НУ “Львівська політехніка". Радіоелектроніка та телекомунікації. - 2016. № 849. - С. 99-116.

21. Мережин, Н. И. Экспериментальные исследования системы намагничивания рельсов с использованием постоянных магнитов [Текст] / Н. И. Мережин, М. Н. Максимов, А. А. Легин // Известия ЮФУ. Технические науки. - 2014. № 11 (160). - С.135-145.

22. Намагничивающая система. ООО НПФ "Полюс-Н" [Электронный ресурс]. - Режим доступа: http://www.polus-n.com/defectoscop.html.

23. Dover, W. The use of AC-field measurements for crack detection and sizing in air and underwater [Text] 
/ W. Dover, R. Collins, D. Michael. - Phil. Trans. R. Soc. Lond., 1986. - Vol. 320 A. - P. 271-283.

24. Hughes, G. A Robotic End Effector for Visual and Electromagnetic Inspection of Waste Storage Tank Walls [Text] / G. Hughes, M. Gittleman // The ANS $6^{\text {th }}$ Topical Meeting on Robotics and Remote Systems. - La Grange Park, (IL, USA), 1995. - P. 347-354.

25. Gaynor, T. M. Reduction in Fatigue Failures through Crack Detection by Alternating Current Field Measurements [Text] / T. M. Gaynor, D. L. Roberts, E. Holman, W. D. Dover // IADC/SPE Drilling Conference. - New Orleans (Louisiana, USA), 12-15 March 1996. - 35033 Conference Paper.

26. Topp, D. Use of the ACFM Inspection Method to reduce Downhole Drillstring Failures [Text] / D. Topp // Australia Oil \& Gas Conference, 2001.

27. Howitt, M. Bombardier brings ACFM into the Rail Industry [Text] / M. Howitt // Insight. - 2002. Vol. 44. - № 6. - P. 379-382.

28. Topp, D. Application of the ACFM inspection method to rail and rail vehicles [Text] / D. Topp, M. Smith // Insight. - 2005. - Vol. 47. - № 6. - P. 354-357.

29. Lugg, M. Recent developments and applications of the ACFM inspection method and ACSM stress measurement method [Text] / M. Lugg, D. Topp // $9^{\text {th }}$ European Conference on NDT. - Berlin (Germany), September 2006. - Tu. 3.6.5.

30. Lugg, M. Applications of ACFM for Weld Inspection by ROV [Text] / M. Lugg // Singapore International NDT Conference \& Exhibition. - Singapore, 3-4 November 2011. - 8 p.

31. Thomas, H. M. Pioneering inspection of railroad rails with eddy currents [CD] / H. M. Thomas, M. Junger, H. Hintze, R. Krull, S. Rühe $/ / 15^{\text {th }}$ World Conference on NDT. - Roma (Italy), 2000.

32. Krull, R. Eddy current detection of head-checks on the gauge corner of rails: Recent results [CD] / R. Krull, H. M. Thomas, R. Pohl, S. Rühe // $6^{\text {th }}$ International Conference \& Exhibition on Railway Engineering. Edinburgh-London: Engineering Technics Press, 2003. -8 p.

33. Krull, R. Non-destructive testing of rails today and in the future [Text] / R. Krull, H. Hintze, M. Thomas, T. Heckel // ZEVrail Glasers Annalen. - 2003. № 127. - P. 286-296.

34. Pohl, R. A new eddy current instrument in a grinding train [Text] / R. Pohl, R. Krull, R. Meierhoffer // $9^{\text {th }}$ European Conference on NDT. - Berlin (Germany), September 2006. - Poster 178.

35. Thomas, H. Advantage of a combined ultrasonic and eddy current examination for railway inspection trains [Text] / H. Thomas, T. Heckel, E. Hanspach // $9^{\text {th }}$ European Conference on NDT. - Berlin (Germany), September 2006. - Wed. 4.5.3.

36. Совмещенный вагон-дефектоскоп. - [Електронний peсурс ] - Режим доступу: http://vsz.gomel.by/index.php/ru/vagons/specialnogonaznacheniya/252-sovmeschennyi-vagondefektoskop.html.

37. Вагони-дефектоскопи ВД-УМТ-1. - [Електронний ресурс] - Режим доступу: https://tvema.all.biz/vagony-defektoskopy-vd-umt-1g874151.

38. Вагони-дефектоскопи ВД-УМТ-2. - [Електронний pecypc] - Режим доступу: https://tvema.ru/516.

39. Matiieshyn, Yu. Modern methods of mobile diagnostics of railway tracks defects [Text] / Yu. Matiieshyn, V. Nichoha, V. Shkliarskyi, V. Storozh, L. Vashchyshyn, M. Borovets, P. Zhuk // Advanced Rail Technologies ART'2017 : 6th Int. Conf., 15-16 November 2017: Proceedings. - Warsaw (Poland), 2017. - P. 71.

40. Saldan, O. Experimental Research of Signals of Defects Such as the Transverse Cracks on the Rail Imitator [Text] / O. Saldan, V. Nichoha, V. Storozh, I. Storozh, I. Stefanyshyn // Modern Problems of Radio Engineering, Telecommunications and Computer Science TCSET'2016 : XIII Int. Conf., 23-26 February 2016 : Proceedings. - Lviv-Slavske (Ukraine), 2016. - P. 222-225.

41. Nichoga, V. Kierunki w modernizacji lwowskiego wagonu-defektoskopu magnetycznego przy zastosowaniu magneto-dynamicznej metody diagnostyki szyn torow kolejowych [Tekst] / V. Nichoga, I. Prudyus, I. Storozh, V. Storozh, L. Vashchyshyn // Transport XXI wieku: Międzynarodowa konferencja naukowa, 30 sierpnia 2 września 2016. - Arłamów (Polska), 2016. S. 339-340.

42. Нічога, В. О. Аналіз сигналів дефектів залізничних рейок у програмі Matlab Wavelet Toolbox [Текст] / В. О. Нічога, Л. В. Ващишин, О. В. Салдан // Вісник НУ “Львівська політехніка" Радіоелектроніка та телекомунікації. - 2014. № 796. - C. 8-13.

43. Nichoga, V. Model of rail crack based on a discrete set of loops with current [Text] / V. Nichoga, I. Storozh, L. Vashchyshyn // Diagnostyka. Warsawa: PTDT, 2013. - Vol. 14. - № 2. - S. 67-71.

44. Блок спряження багатоканального магнітного дефектоскопа рейок: Патент № 77065 Україна, МПК G11B 20/10 (2006.01). / В. О. Нічога, I. B. Сторож; заявник та власник патенту Національний університет “Львівська політехніка”. - № u201208870 ; заявл. 18.07.2012; опубл. 25.01.2013.

45. Сторож, I. В. Восьмиканальний активний давач для магнітної діагностики залізничної колії [Текст] / I. В. Сторож, В. О. Нічога // Вісник НУ "Львівська політехніка" - Радіоелектроніка та телекомунікації. - 2011. - № 705. - С. 171-175. 
Ничога В. А., Шклярский В. И., Сторож В. Г., Матиешин Ю. Н., Ващишин Л. В. Исследование современных методов и средств скоростной диагностики дефектов железнодорожных рельсов (Обзор). Задачей мобильной диагностики дефектов железнодорожных путей является выявление и распознавание опасных дефектов с целью предупреждения возможных аварий. Обзор методов контроля физико-механических характеристик металлических конструкций инженерных объектов долговременной эксплуатации, которые используются при различных температурных режимах и условиях, осуществлен в $[1,2] . \quad$ Среди описанных неразрушающих методов по используемым физическим полям выделяют: магнитные, акустические, электромагнитные, тепловые и электрические.

Ключевые слова: информационно-диагностическая система, дефектоскопия железнодорожных путей, компонентные датчики, неразрушающие магнитные методы, вейвлет-анализ и нейронные сети.

Nichoha V. O., Shkliarskyi V. I., Storozh V. G., Matiieshyn Y. M., Vashchyshyn L. V. The Research of modern methods and means of high-speed diagnostics of railway rails defects (Review). The task of mobile railway tracks defects diagnostics is to identify and recognize dangerous defects in order to prevent possible accidents. A review of the methods for controlling the physical and mechanical characteristics of metal constructions of engineering objects of long-term exploitation, which are used under different temperature regimes and conditions, is carried out in $[1,2]$. Among the described non-destructive methods on the used physical fields are allocated: magnetic, acoustic, electromagnetic, thermal and electrical. Electromagnetic methods are successfully used in various industries, such as the railway industry, the metal-working industry, drilling, nuclear waste storage and so on [3]. In particular, in the railway industry, using the technique of measuring the electromagnetic field of an alternating current, checks of carriages, wheel pairs and tracks are carried out. Recently, hybrid systems of diagnostics on the basis of carriagesdefectoscopes are actively used to detect defects in railway tracks [1].

Keywords: information diagnostic system, railway tracks defectoscopy, component sensors, non-destructive magnetic methods, wavelet analysis and neural networks.

Надійшла 15.05.2018 p.
Нічога Вімалій Олексійович, доктор технічних наук, професор кафедри радіоелектронних пристроїв та систем інституту телекомунікацій, радіоелектроніки та електронної техніки, Національного університету «Львівська політехніка», Львів, Украӥна. E-mail: nich@org.lviv.net ORCID ID: https://orcid.org/00000001-6412-3120

Шклярський Володимир Іванович, доктор технічних наук, професор кафедри радіоелектронних пристроїв mа систем інституту телекомунікацій, радіоелектроніки та електронної техніки, Національного університету «Львівська політехніка», Львів, Україна. E-mail: shkliarskyi@ukr.net ORCID ID: https://orcid.org/0000-0001-8806-9202

Сторожс Володимир Георхійович, кандидат технічних наук, дочент кафедри радіоелектронних пристроїв та систем інституту телекомунікацій, радіоелектроніки та електронної техніки, Національного університету «Львівська політехніка», Львів, Україна. E-mail: volodymyr.h.storozh@lpnu.иа ORCID ID: https://orsid.org/0000-0002-4776-2729

Матісшин Юрій Миколайович, кандидат технічних наук, асистент кафедри радіоелектронних пристроїв та систем інституту телекомунікацій, радіоелектроніки та електронної техніки, Національного університету «Львівська політехніка», Львів, Україна. E-mail: yurii.m.matiieshyn@lpnu.иа ORCID ID: https://orcid.org/0000-0001-8498-3398

Ващциин Любомир Володимирович, молодиий науковий співробітник кафедри радіоелектронних пристроїв та систем інституту телекомунікацій, радіоелектроніки та електронної техніки, Національного університету «Львівська політехніка», Львів, Україна. E-mail: vashchyshyn.liubomyr@gmail.com https://orcid.org/0000-0002-3513-0361 ORCID ID:

Nichoha Vitalij Oleksiyovych, Doctor of Technical Sciences, Professor of the Department of Radioelectronic Devices and Systems, Institute of Telecommunications, Radioelectronics and Electronic Engineering, Lviv Polytechnic National University, Lviv, Ukraine. E-mail: nich@org.lviv.net ORCID ID: https://orcid.org/00000001-6412-3120

Shkliarskyi Volodymyr Ivanovych, Doctor of Technical Sciences, Professor of the Department of Radioelectronic Devices and Systems, Institute of Telecommunications, Radioelectronics and Electronic Engineering, Lviv Polytechnic National University, Lviv, Ukraine. E-mail: shkliarskyi@ukr.net ORCID ID: https://orcid.org/00000001-8806-9202 
Storozh Volodymyr Georgiyovych, Candidate of Technical Sciences, Associate Professor of the Department of Radioelectronic Devices and Systems, Institute of Telecommunications, Radioelectronics and Electronic Engineering, Lviv Polytechnic National University, Lviv, Ukraine. E-mail: volodymyr.h.storozh@lpnu.ua ORCID ID: https://orsid.org/0000-0002-4776-2729

Matiieshyn Yurij Mykolayovych, Candidate of Technical Sciences, Assistant Professor of the Department of Radioelectronic Devices and Systems, Institute of Telecommunications, Radioelectronics and Electronic Engineering, Lviv Polytechnic National University, Lviv, Ukraine. E-mail: yurii.m.matiieshyn@lpnu.ua ORCID ID: https://orcid.org/0000-0001-8498-3398

Vashchyshyn Liubomyr Volodymyrovych, Junior Research Fellow of the Department of Radioelectronic Devices and Systems, Institute of Telecommunications, Radioelectronics and Electronic Engineering, Lviv Polytechnic National University, Lviv, Ukraine. E-mail: vashchyshyn.liubomyr@gmail.com_ORCID ID: https://orcid.org/0000-0002-3513-0361 